\title{
HEIKKI PASANEN
}

\section{Kriittisen teorian näkökulma aikuiskasvatukseen}

Kanadalainen aikuiskasvatuksen professori Michael Collins on nostanut Frankfurtin koulukunnan kriittisen teorian näkökulmaksi, jonka kautta hän käsittelee aikuiskasvatuksen ammatillistumisen problematiikkaa. Kriittisen teorian traditiosta nousee esille kaksi tärkeää yhtymäkohtaa käsiteltävään teemaan: teknologiakritiikki ja kommunikatiivisuus.

\section{Teknologiakritiikki ja aikuiskasvatus}

Teknologiakritiikin kohteena ei ole sinänsä tekniikan kritiikki eikä se tarkoita a priori negatiivista suhdetta tekniikkaan esimerkiksi opetuksellisten välineiden kehittämisen osalta. Tuo kritiikki kyseenalaistaa sellaiset näkemykset, jotka pitävät joitakin asioita puhtaina totuuksina ilman arvoja. Erilaiset suuret totuudenvartijat ja ajattelutavat, joissa nähdään asioilla olevan vain yksi oikea puolensa, asettuvat kritiikin kohteeksi. Teknologia on saavuttanut kylläkin helposti tällaisen aseman, luonnontieteiden ja uskonnon ohella.

Totuuden perusteiden osalta nuo näkemykset ovat nostaneet itsensä kritiikin ulottumattomiin. Ne pyrkivät esittäytymään arvoista vapaina, "puhtaina" keinoina, jotka ovat kritisoitavissa vasta käyttäjiensä arvojen mukaisen toiminnan kautta. Collins näkee, että tällainen teknokraattinen näkemys on vakiintumassa professioitumisen myötä myös aikuiskasvatukseen. Aikuiskasvatustieteen valtavirraksi on jo muodostunut teknis-rationaalinen ajattelutapa, jossa menetelmien ylivalta ja tehokkuuspyrkimyksen kultti ovat keskeisiä arvoja. Aikuiskoulutuksen tehokkuuspyrkimys vie sen irralleen arkipäivän elämiseen kuuluvasta käytännöstä. Tiede kehittää tämän vuoksi menetelmällisiä keinoja pystyäkseen ottamaan haltuun ja kontrolloimaan aikuisten "'etäiset" oppimisaktiviteetit.

Objektivoivat menetelmälliset keinot, yksilöpsykologiset koulutustarvearvioinnit, koulutus- ja opetusohjelmasuunnittelu samoin kuin pedagogiset menetelmät itse opetuksessa, oppimisympäristöt ym. ohjataan ja opetetaan rakentamaan standardeiksi, systemaattisesti etukäteen suunnitelluiksi oppimispaketeiksi. Tällöin teoria ei reflektoidu

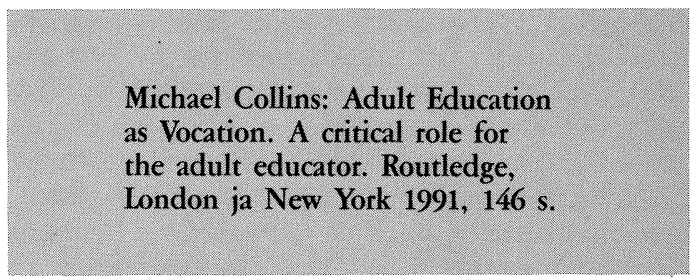

kriittisesti muuttuvasta sosiaalisesta käytännöstä. Samalla aikuisopiskelija käsitetään pelkästään neutraaliksi asiakkaaksi (client). Tämä orientaatio on läpikäyvänä myös suunnittelussa, jossa mitä tahansa koulutusta legitimoidaan elinikäisen oppimisen sloganilla.

\section{Yksilösuuntautuneisuuden näköalattomuus}

Opetustapahtumaan on lyöty viime aikoina "'itseohjautuvuuden", "oppijakeskeisyyden" ja "yksilöpedagogiikan" leimoja, jolloin vältytään ottamasta kantaa koulutuksen arvopäämääriin, kohderyhmiin ym. "Asiakkaat" nähdään abstrakteina yksilöinä, joiden koulutukselliset toiveet ikään kuin leijuvat ilmassa vailla sosiaalisesta kontekstista nousevia tarpeita, mutta jotka professioitunut ekspertti kyllä voi menetelmillään täyttää.

Collinsin kritiikki kohdistuu selkeästi Knowlesin edustamaan andragogiaan, jonka hän näkee vaikuttavaksi osaksi eettiset periaatteensa unohtaneesta aikuiskasvatuksen valtavirrasta. Aikuiskasvattajan rooliin ei kuulu koulutuksen/kasvatuksen tavoitteiden ajatteleminen - hän toimii pelkästään teknisenä menetelmällisenä avustajana ja oppimisprosessin tukijana. Muuttaessaan radikaalisti painopisteen opettajakeskeisyydestä opiskelijakeskeisyyteen on aikuiskasvattajan toimiminen itseohjautuvan opiskelun auttajana johtamassa tilanteeseen, jossa myös opiskelijat ovat alistettuja valtavirran koulutustarjonnalle (koulutusmalleille ja -sisällöille). Sen tehtävänä on useimmiten taloudellis-teknisen ekspansion tien tasoittaminen koulutuksen keinoin. Hyväksyessään kritiikittömästi tekniset ja yksinkertaistetut koulutusmallit aikuiskasvattaja tulee taloudellisten, byrokraattisten ja poliittisten intressien saaliiksi. 
Collins kysyykin näennäisen naiivisti " kenen intressejä $\mathrm{mm}$. yksilöpsykologisesti orientoitunut koulutussuunnittelu palvelee?"

Kysymys intressistä on kuitenkin kriittisen teorian näkökulmasta aiheellinen, koska se yhdistyy kysymyksiin, mitä koulutusta tuotetaan, miksi ja mitä tarkoitusta koulutus palvelee? Aiheelliseksi kysymyksen tekee myös tilanne, jossa koulutusta tuotetaan selkeästi kaupallisen taloudellisuus- ja tehokkuuskilpailun ja -periaatteen ohjaamana. 'Arvottomat' kouluttajat, opettajat ja koulutuksen suunnittelijat ovat tuottajan puolella - asiakkaiksi ja koulutettaviksi valikoituu todennäköisin eli maksukykyisin asiakastyhmä. Näin tapahtuu etenkin silloin, kun aikuiskasvattajilla ei ole vaihtoehtoisia (tai minkäänlaisia) eettisiä näkemyksiä suunnittelunsa ja opetuksensa ohjaajana.

Näiden puuttuessa yksilöpsykologinen teknokraattinen suunnittelu tulee palvelemaan vastaavasti utilitarismin filosofiassa esiintyvää " jokamiestä". Joka mies puolestaan edustaa kasvotonta, status quota säilyttävää, ei muuttavaa intressiä. Muuttuvassa maailmassa ja yhteiskunnassa tämä on paradoksi sen ohella, että itse "yksilökeskeisyyden" periaate osoittautuu itse asiassa hylkäävän kaiken uniikin yksilöllisyyden.

\section{Arvot ja ammattietiikka}

Arvioidessaan nykyistä aikuiskasvatuksen käytäntöä ja tutkimusta, koulutustarpeiden arviointia, suunnittelua ja evaluaatiota, Collins tulee johtopäätökseen, että alan professioituminen ohjautuu teknis-rationaalisten arvoperustojen mukaisesti. Ammattikäytännön eettiset ja historialliset periaatteet sekä yleensä aikuiskasvatuksen eettiset kysymykset jätetään tässä orientaatiossa syrjään.

Collins nostaa esille ammatin (vocation $=$ myös kutsumus) käsitteen, joka ' 'korostaa ammatinharjoittajan persoonallista vastuuta, jota ei voida korvata teknisin määräyksin eikä ennalta asetetuin muotoiluin, jotka ovat ominaisia tehokkuuskultille". Kompetentti toiminta eräänä ammatin aspektina ei tee välttämättömäksi ennaltamäärättyjen taitokimppujen hallintaa, käyttäytymistä tai pätevyyksiä, vaan se on käsitettävissä praktisin ja eettisin termein. Tehokkuus ja eksperttiys ovat sekundaarisia inhimillisen hyvinvoinnin, oikeudenmukaisuuden ja tasa-arvon eettisten periaatteiden toteuttamisen suhteen.

\section{Muuttava pedagogiikka}

Collinsin näkemyksen mukaan aikuiskasvattaja ei voi toimia edellisten periaatteiden mukaan ilman persoonallista sitoutumista, ja ilman yo. periaatteita aikuiskasvatus puolestaan edustaa modernia "arvottomuuden" etiikkaa - valtaapitävien teknologiaa. Collinsin näkemyksessä ammatillinen etiikka yhdistyy kriittiseen ja muuttavaan (transformative) pedagogiaan.

Vaihtoehtoliikkeet edustavat jo itsessään kriittistä reflektiota, tuottavat näkökulmia ja diskurssia, jonka kommunikatiiviset funktiot ovat merkittäviä myös yhteiskuntaeettisten ja periaatteellisten tulevaisuuden kysymysten suhteen. Yhteiskunnallisesti alistettujen ja deprivoitujen ryhmien kasvatus- ja koulutusintressit eivät saa vastinettaan valtavirran nykyisessä koulutusideologiassa. Edellisiin liittyen erilaiset osallistuvan tutkimuksen, yhteisökasvatuksen ja yhteisöjen kehittämiseen tähtäävät koulutukselliset projektit edustavat muuttavaa pedagogiaa.

Yhteisyyttä (kommunikaatiota) ja yhteisöllisyyttä näyttää Collins pitävän ikään kuin eettisten periaatteiden toteutumisen takeena. Vaikka klassiset eettiset periaatteet eivät etenkään nykyisen koulutuksen kaupallistumisen myötä ainakaan näytä menettävän arvoaan, täytyy aikuiskasvatuksen pystyä ylläpitämään sosiaalis-kommunikatiivinen sidos yhteiskunnalliseen käytäntöön. Vasta tällöin voidaan myöskin arvioida periaatteiden toteutumista, aikuiskasvatuksen vaikutuksia ja merkitystä. Aikuiskasvattajalle ei toisin sanoen riittäisi oppimistilaisuuksien ja -mahdollisuuksien luominen, vaan myös huolehtiminen kysymyksestä, mitä vaikutuksia tai muutoksia koulutuksella pyritään saamaan tai saadaan aikaan.

Collins tuo selkeästi esille oman ajattelunsa tausta- vaikuttajia kriittisen koulukunnan ohella; tekstissä esiintyvät mm. Alfred Schutz ja toimintojen merkitys, Michel Foucault ja vallan analyysi, John Rawls ja oikeudenmukaisuusteoria. (Aikuis)kasvattajien puolelta näkökulman muotoilussa näkyvät mm. Eduard Lindeman, John Dewey, Ivan Illich ja erityisesti Paolo Freire. Erityisen merkityksen nykykeskustelussa saa Habermasin kommunikatiivisen toiminnan teoria.

Collins pitää eurooppalaista aikuiskasvatuskeskustelua teoreettisesti monipuolisempana verrattuna pohjois-amerikkalaiseen psykologisointiin. Hän on halunnut herättää keskustelun kasvattajien ammattietiikasta tilanteessa, jossa koulutuksen tehokkuus- ja taloudellisuusvaatimuksista ollaan sikäläisittäin vasta keskustelemassa.

Suomi ei aikuiskoulutusuudistusten osalta todennäköisesti kuulu tuohon keskustelevaan eurooppalaiseen kerhoon, johon hän viittaa. 